\title{
Regional hyperthermia combined with chemotherapy in paediatric, adolescent and young adult patients: current and future perspectives
}

\author{
Georg Seifert ${ }^{1 *}$, Volker Budach², Ulrich Keilholz ${ }^{3}$, Peter Wust ${ }^{2}$, Angelika Eggert ${ }^{1}$ and Pirus Ghadjar ${ }^{2}$
}

\begin{abstract}
Here we evaluate the current status of clinical research on regional hyperthermia (RHT) in combination with chemotherapy or radiation therapy in paediatric oncology.

Data were identified in searches of MEDLINE, Current Contents, PubMed, and references from relevant articles using medical subject headings including hyperthermia, cancer, paediatric oncology, children, radiation therapy and chemotherapy. Currently, only two RHT centres exist in Europe which treat children. Clinical RHT research in paediatric oncology has as yet been limited to children with sarcomas and germ cell tumours that respond poorly to or recur after chemotherapy. RHT is a safe and effective treatment delivering local thermic effects, which may also stimulate immunological processes via heat-shock protein reactions. RHT is used chiefly in children and adolescents with sarcomas or germ cell tumours located in the abdomino-pelvic region, chest wall or extremities to improve operability or render the tumour operable. It could potentially be combined with radiation therapy in a post-operative R1 setting where more radical surgery is not possible or combined with chemotherapy instead of radiation therapy in cases where the necessary radiation dose is impossible to achieve or would have mutilating consequences. RHT might also be an option for chemotherapy intensification in the neoadjuvant first-line treatment setting for children and adolescents, as was recently reflected in the promising long-term outcome data in adults with high-risk soft tissue sarcomas (EORTC 62961/ESHO trial).

The limited data available indicate that combining RHT with chemotherapy is a promising option to treat germ cell tumours and, potentially, sarcomas. RHT may also be beneficial in first-line therapy in children, adolescents and young adults. The research should focus on optimising necessary technical demands and then initiate several clinical trials incorporating RHT into interdisciplinary treatment of children, adolescents and young adults that include translational research components exploring potential immunological mechanisms of action.
\end{abstract}

\section{Introduction - current situation}

In contrast to adult oncology, tumours of mesenchymal and neuroectodermal origin predominate in paediatric oncology. While sarcomas occur in all age groups, they are relatively more common in children and adolescents than later in life. In the course of the years, co-operative treatment optimisation studies have led to marked optimisation

\footnotetext{
* Correspondence: georg.seifert@charite.de

'Department of Paediatric Oncology and Haematology, Otto-Heubner Centrum für Kinder- und Jugendmedizin, Charité - Universitätsmedizin Berlin, Augustenburger Platz 1, 13353 Berlin, Germany

Full list of author information is available at the end of the article
}

of systemic polychemotherapy, for example for the group of soft tissue sarcomas [1]. The possibilities for optimisation of these conventional chemotherapy protocols appears to have reached a level where only new mechanisms of action and innovative strategies can produce further improvements with clinical relevance. Epigenetic and immunological treatment approaches can be expected to play an increasing role in the coming years, but these are still at the stage of clinical development. Successful treatment for sarcomas incorporates both effective systemic neo-/adjuvant therapy and local control even when the tumour has metastasised to improve overall survival (OS) [2]. Despite a 
frequently unfavourable location of the primary tumour, the aim is always to permit R0 resection with as little functional loss as possible. Here there have also been marked improvements in both surgical and radiation therapy strategies in the past years and new techniques have been introduced. In spite of modern radiation therapy techniques such as proton therapy, stereotactic radiation therapy or radiosurgery, and experimental procedures such as isolated limb perfusion chemotherapy, effective local therapy can present a success-limiting problem in the individual case. But even in the case of effective local therapy, acute and long-term side effects of surgery and/or radiation therapy can present a relevant problem.

Regional hyperthermia (RHT), offers an interesting approach that acts synergistically with chemotherapy and radiation therapy without producing disproportionate additional side effects, provided that current quality assurance guidelines for treatment planning and application are followed [3-5]. The rationale is a synergistic thermic chemosensitation through the use of alkylating substances such as cyclophosphamide or ifosfamide, platinum derivatives or anthracyclines [6] as established in the Hyper-PEI protocol and the german study group for malignant germ cell tumors (MAKEI) [7]. RHT in combination with chemotherapy is the best investigated thermotherapy procedure in both adult and paediatric oncology to date $[8,9]$. This review aims to summarize the current knowledge on RHT in the treatment of paediatric, adolescent and young adult patients and provide some discussion points and future perspectives.

\section{Methods}

Data for this paper were identified by searches of MEDLINE, Current Contents, PubMed, and references from relevant articles using medical subject headings including hyperthermia, cancer, paediatric oncology, children, radiotherapy and chemotherapy.

\section{Results}

\section{Regional hyperthermia with chemotherapy}

The search strategy identified six reports on prospective clinical trials without control groups (Table 1). The data on RHT or hyperthermic chemotherapy in children and adolescents are currently limited, and only two active German hyperthermia centres treating paediatric patients were identified, the Heinrich Heine University Hospital Düsseldorf and the Charité-Universitätsmedizin Berlin. The study by Romanowski et al. was the first which combined RHT and systemic chemotherapy (ICE: etoposide $4 \times 150 \mathrm{mg} / \mathrm{m}^{2}$ and ifosfamide $4 \times 2000 \mathrm{mg} / \mathrm{m}^{2}$ or carboplatin $4 \times 150 \mathrm{mg} / \mathrm{m}^{2}$ ) in 34 intensively pretreated children and adolescents with prognostically unfavourable tumour diseases [10]. Romanowski et al. reported that $20 \%$ of patients experienced a complete remission and 7 patients remained alive up to 64 months after the combined treatment. A second pilot trial treated 9 patients with locoregional recurrences of abdominal germ cell tumors with PEI chemotherapy (PEI: cisplatin $40 \mathrm{mg} / \mathrm{m}^{2}$ on days 1 and 4 , etoposide $100 \mathrm{mg} / \mathrm{m}^{2}$ on days 1 to 4 and ifosfamide $2000 \mathrm{mg} / \mathrm{m}^{2}$ on days 1 to 4 ) in combination with RHT but with or without radiation treatment. Event-free survival (EFS) in these 9 patients (EFS $0.41 \pm 0.33$ ) who received RHT was significantly better than in a matched cohort (EFS $0.16 \pm 0.25$ ) who did not receive RHT, supporting the idea that RHT can have a relevant impact on local tumor control and patient EFS [11]. A further report on 10 patients from a phase I/II trial in children and adolescents with recurrent or refractory germ cell tumours treated at the University Hospital Düsseldorf with RHT combined with platinum-based PEI chemotherapy demonstrated feasibility and efficacy with objective tumour response rates up to $70 \%$ [12]. Of these 10 patients, 2 responded partially and 5 had a complete response. Schneider et al. reported on a prospective trial without a control group for patients with relapsed malignant sacrococcygeal germ cell tumours who received cisplatin-based first-line polychemotherapy and tumour resection according to the MAKEI trial [7]. In this trial, 22 patients with first relapses, 14 with second relapses and 7 with later relapses were treated by surgery and adjuvant platinum chemotherapy. Pre-operative chemotherapy was administered together with RHT with the aim to improve operability in a subgroup of 8 poor responders or patients with locally advanced tumours. Although the small number of patients limits the informative value, the effect of RHT in this study was better when applied early resulting in 4 complete remissions after first or second relapses.

The group of Wessalowski at the University Hospital Düsseldorf published two further trials. The first trial included 39 patients, 24 with extracranial non-testicular germ cell tumours and 15 with soft tissue sarcomas or chondrosarcomas, of which 29 tumours were locoregional relapses and 10 were unresectable following pre-operative chemotherapy. Of these 39 patients treated with RHT according to the Hyper-PEI protocol, 20 achieved complete remission and 10 achieved partial remission. A consecutive surgical tumour resection was possible in 28 of these patients, while 13 patients required additional radiotherapy. After 5 years of follow-up, EFS was $0.39 \pm 0.11(20 / 39$ patients) and OS was $0.52 \pm 0.11$ (25/39 patients). This interdisciplinary treatment of RHT with chemotherapy enabled a successful local therapy leading to a sustained remission in most patients with high risk for tumour recurrence [9]. Wessalowski et al. also used RHT in combination with chemotherapy for salvage treatment in 44 children and adolescents with refractory or recurrent nontesticular malignant germ-cell tumours [8]. Sufficient data could only be obtained for 35 of the 44 patients, of which 
Table 1 Design of clinical studies employing regional hyperthermia with chemotherapy

\begin{tabular}{|c|c|c|c|c|c|c|c|}
\hline Reference & Indication & Research design & $\begin{array}{l}\text { Schedule of } \\
\text { Hyperthermia/Number } \\
\text { of sessions }\end{array}$ & $\begin{array}{l}\text { Chemotherapy/Number of } \\
\text { courses }\end{array}$ & Number of patients & Outcome measure & Comment \\
\hline $\begin{array}{l}\text { Romanowski Klinische } \\
\text { Pädiatrie } 1993 \text { [10] }\end{array}$ & $\begin{array}{l}\text { Different solid } \\
\text { tumors with } \\
\text { prognostically } \\
\text { unfavorable } \\
\text { tumor diseases }\end{array}$ & $\begin{array}{l}\text { Feasibility of regional } \\
\text { hyperthermia with } \\
\text { systemic chemotherapy }\end{array}$ & $\begin{array}{l}\text { Day } 1 \text { and } 4 \\
\text { simultaneously to the } \\
\text { chemotherapy (2-16 } \\
\text { RHT sessions per } \\
\text { patient; mean 6,5) }\end{array}$ & $\begin{array}{l}16 \text { patients: IE: etoposide } 4 \times \\
150 \mathrm{mg} / \mathrm{m}^{2} \text { and ifosfamide } 4 \times \\
2000 \mathrm{mg} / \mathrm{m}^{2} \\
8 \text { patients: ICE: etoposide } 4 \times \\
150 \mathrm{mg} / \mathrm{m}^{2} \text { and ifosfamide } 4 \times \\
2000 \mathrm{mg} / \mathrm{m}^{2} \text { or every } 2 \mathrm{nd} \mathrm{cycle} \\
\text { carboplatinum } 4 \times 150 \mathrm{mg} / \mathrm{m}^{2} \\
10 \text { patients received various } \\
\text { substances including adriamycin } \\
\text { Mean } 3 \text { treatment courses }\end{array}$ & $\begin{array}{l}34 \text { (age: mean } \\
11 \text { years: } 6 \text { month) }\end{array}$ & Feasability study & $\begin{array}{l}\text { First study in } \\
\text { children and } \\
\text { adolescents on } \\
\text { RHT and } \\
\text { Chemotherapy } \\
20 \% \text { complete } \\
\text { remission } \\
7 \text { patients were } \\
\text { in CR up to } 64 \\
\text { month }\end{array}$ \\
\hline $\begin{array}{l}\text { Wessalowski R. } \\
\text { Klinische Pädiatrie } \\
1997 \text { [11] }\end{array}$ & $\begin{array}{l}\text { Locoregional } \\
\text { Recurrences } \\
\text { of abdominal } \\
\text { Germ Cell Tumors }\end{array}$ & $\begin{array}{l}\text { Pilot study } \\
\text { PEI-chemotherapy } \\
\text { and RHT compared } \\
\text { to a mached cohort }\end{array}$ & $\begin{array}{l}\text { Day } 1 \text { and } 4 \\
\text { simultaneously to } \\
\text { the chemotherapy } \\
\text { (6-30 RHT sessions } \\
\text { per patient; mean 12,4) }\end{array}$ & $\begin{array}{l}\text { PEl: cisplatinum } 40 \mathrm{mg} / \mathrm{m}^{2} \text { on day } 1 \\
\text { and } 4 \text {; etoposide } 100 \mathrm{mg} / \mathrm{m}^{2} \text { on } \\
\text { day } 1 \text { to } 4 \text { and ifosfamide } 2000 \\
\mathrm{mg} / \mathrm{m}^{2} \text { on day } 1 \text { to } 4 \text { ) } \\
\text { Mean } 6 \text { treatment courses }\end{array}$ & $\begin{array}{l}9 \text { RHT (age: mean } \\
10 \text { years; } 11 \text { month) } \\
23 \text { matched cohort }\end{array}$ & $\begin{array}{l}\text { RHT subgroup } \\
5 \text {-year EFS } \\
0.41 \pm 0.33 \\
(5 \mathrm{CR}, 2 \mathrm{PR} \text {, } \\
1 \mathrm{SD}, 1 \mathrm{PD}) \\
\\
\text { matched cohort } \\
5 \text {-year EFS } \\
0.16 \pm 0.25\end{array}$ & \\
\hline $\begin{array}{l}\text { Wessalowski R. } \\
\text { Cancer. } 1998 \text { [12] }\end{array}$ & $\begin{array}{l}\text { Recurrence of an } \\
\text { Malignant } \\
\text { sacrococcygeal } \\
\text { germ cell tumors }\end{array}$ & Phase I/II study & $\begin{array}{l}\text { Day } 1 \text { and } 4 \\
\text { simultaneously to } \\
\text { the chemotherapy } \\
\text { (6-10 RHT sessions } \\
\text { per patient; mean 8,8) }\end{array}$ & $\begin{array}{l}\text { PEl: cisplatinum } 40 \mathrm{mg} / \mathrm{m}^{2} \text { on } \\
\text { day } 1 \text { and } 4 \text {; etoposide } 100 \\
\mathrm{mg} / \mathrm{m}^{2} \text { on day } 1 \text { to } 4 \text { and } \\
\text { ifosfamide } 2000 \mathrm{mg} / \mathrm{m}^{2} \text { on } \\
\text { day } 1 \text { to } 4) \\
\text { Mean } 4 \text { treatment courses }\end{array}$ & $\begin{array}{l}10 \text { (age: mean } \\
11 \text { years; } 3 \text { month) }\end{array}$ & $\begin{array}{l}\text { Phase I/II study } \\
\text { Toxicity } \\
\text { (5 CR, 2PR, } \\
\text { 1SD. 1NC, 1PD) }\end{array}$ & $\begin{array}{l}\text { WHO grade } 4 \\
\text { neutropenia and } \\
\text { thrombocytopenia } \\
\text { after all cycles } \\
\text { Granulocytopenic } \\
\text { fever after } 27 \% \\
\text { cycles; WHO grade } \\
-3 \text { acute renal } \\
\text { toxicity after } 5 \% \\
\text { cycles; WHO grade } \\
3 \text { mucositis after } \\
11 \% \text { cycles }\end{array}$ \\
\hline $\begin{array}{l}\text { Schneider D. } \\
\text { J Clin Oncol, } \\
2001 \text { [7] }\end{array}$ & $\begin{array}{l}\text { Relapsed or } \\
\text { refractory } \\
\text { germ cell } \\
\text { tumour }\end{array}$ & $\begin{array}{l}\text { Subgroup in a } \\
\text { prospective study } \\
\text { no control group }\end{array}$ & $\begin{array}{l}\text { Day } 1 \text { and } 4 \\
\text { simultaneously } \\
\text { to the chemotherapy }\end{array}$ & $\begin{array}{l}\text { PEl: cisplatinum } 40 \mathrm{mg} / \mathrm{m}^{2} \text { on } \\
\text { day } 1 \text { and } 4 \text {; etoposide } 100 \\
\mathrm{mg} / \mathrm{m}^{2} \text { on day } 1 \text { to } 4 \text { and } \\
\text { ifosfamide } 2000 \mathrm{mg} / \mathrm{m}^{2} \\
\text { on day } 1 \text { to } 4 \text { ) }\end{array}$ & $\begin{array}{l}\text { A subgroup of } 8 \\
\text { Patients (age: mean } \\
11 \text { years; } 3 \text { month) } \\
\text { with RHT out of } 22 \\
\text { first-, } 14 \text { s-, } 5 \text { third-, } \\
\text { and } 2 \text { fourth-relapse }\end{array}$ & $5 \mathrm{CR}, 2 \mathrm{PR}$ & \\
\hline $\begin{array}{l}\text { Wessalowski R. } \\
\text { Klinische Pädiatrie } \\
2003 \text { [9] }\end{array}$ & $\begin{array}{l}\text { Unresectable } \\
\text { malignant } \\
\text { tumours } \\
\text { ( } 24 \text { extracranial } \\
\text { non-testicular germ } \\
\text { cell tumours; } 15 \\
\text { soft tissue or } \\
\text { chondrosarcomas) }\end{array}$ & $\begin{array}{l}\text { Phase-II study } \\
\text { PEl-chemotherapy } \\
\text { and RHT }\end{array}$ & $\begin{array}{l}\text { Day } 1 \text { and } 4 \\
\text { simultaneously } \\
\text { to the chemotherapy } \\
\text { (6-10 RHT sessions per } \\
\text { patient; mean } 8,5)\end{array}$ & $\begin{array}{l}\text { PEl: cisplatinum } 40 \mathrm{mg} / \mathrm{m}^{2} \\
\text { on day } 1 \text { and } 4 \text {; etoposide } \\
100 \mathrm{mg} / \mathrm{m}^{2} \text { on day } 1 \text { to } \\
4 \text { and ifosfamide } 2000 \\
\left.\mathrm{mg} / \mathrm{m}^{2} \text { on day } 1 \text { to } 4\right) \\
\text { Three to four treatment courses }\end{array}$ & $\begin{array}{l}24 \text { Germ cell tumours } \\
\text { (age: mean } 3 \text { years; } \\
7 \text { month) } \\
15 \text { Soft tissue sarcoma } \\
\text { (age: mean } 7 \text { years; } \\
6 \text { month) }\end{array}$ & $\begin{array}{l}\text { Whole study cohort } \\
\text { median follow- } \\
\text { up } 27 \text { months } \\
5 \text {-year EFS } 0.39+/- \\
0.11 \text { ( } 20 / 39 \text { patients) } \\
5 \text {-year OS } 0.52+/- \\
0.11 \text { ( } 25 / 39 \text { patients) }\end{array}$ & $\begin{array}{l}13 \text { patients } \\
\text { received local } \\
\text { radiotherapy }\end{array}$ \\
\hline
\end{tabular}

\section{PEl-chemotherapy and RHT compared} simultaneously to the chemotherapy (6-30 RHT sessions per patient; mean 12, 16 patients: IE: etoposide $4 x$ $\mathrm{mg} / \mathrm{m}^{2}$ arboplatinum $4 \times 150 \mathrm{mg} / \mathrm{m}^{2}$

Mean 3 treatment courses

RHT subgroup 5 -year EFS

Phase I/II study Pay 1 and 4 ; etoposide 100 $\mathrm{mg} / \mathrm{m}^{2}$ on day 1 to 4 and day 1 to 4 )

A subgroup of 8 atients (age: mean with RHT out of 22 first-, 14 s-, 5 third-, ( fourch-relapse (age: mean 7 years: Three to four treatment courses 
Table 1 Design of clinical studies employing regional hyperthermia with chemotherapy (Continued)

\begin{tabular}{|c|c|c|c|c|c|c|c|}
\hline $\begin{array}{l}\text { Wessalowski R. } \\
\text { The Lancet } \\
\text { Oncology, } 2013 \text { [8] }\end{array}$ & $\begin{array}{l}\text { Relapsed or refractory } \\
\text { germ cell tumour }\end{array}$ & $\begin{array}{l}\text { Prospective study } \\
\text { no control group }\end{array}$ & $\begin{array}{l}\text { Day } 1 \text { and } 4 \\
\text { simultaneously } \\
\text { to the chemotherapy } \\
\text { (6-10 RHT sessions } \\
\text { per patient; mean 8,2) }\end{array}$ & $\begin{array}{l}\text { PEl: cisplatinum } 40 \mathrm{mg} / \mathrm{m}^{2} \\
\text { on day } 1 \text { and } 4 \text {; etoposide } \\
100 \mathrm{mg} / \mathrm{m}^{2} \text { on day } 1 \text { to } 4 \\
\text { and ifosfamide } 2000 \mathrm{mg} / \mathrm{m}^{2} \\
\text { on day } 1 \text { to } 4 \text { ) } \\
\text { Three to four treatment courses }\end{array}$ & $\begin{array}{l}44 \text { (age: median } \\
2 \text { years; } 7 \text { months) }\end{array}$ & $\begin{array}{l}\text { response to treatment } \\
16 \text { patients had } \\
\text { CR and } 14 \text { had PR } \\
\text { median follow- } \\
\text { up } 82 \text { months } \\
5 \text {-year event- } \\
\text { free survival } \\
\text { was } 62 \% \\
(95 \% \text { Cl } 45-75) \\
5 \text {-year overall } \\
\text { survival was } \\
72 \%(95 \% \\
\text { Cl } 55-83) \text {. }\end{array}$ & $\begin{array}{l}\text { Local radiotherapy } \\
\text { if incompletely } \\
\text { resected } \\
\text { WHO grade 3-4 } \\
\text { neutropenia and } \\
\text { thrombocytopenia } \\
\text { after every cycle. } \\
\text { Granulocytopenic } \\
\text { fever in } 29 \text { ( } 66 \% \text { ) } \\
\text { of } 44 \text { patients after } \\
53(29 \%) \text { cycles. } \\
\text { WHO grade-3 } \\
\text { acute renal toxic } \\
\text { effects in five } \\
\text { patients }\end{array}$ \\
\hline
\end{tabular}


30 (86 \%) had an objective response to the combination of RHT and PEI chemotherapy. PEI-regional deep hyperthermia utilised $40 \mathrm{mg} / \mathrm{m}(2)$ cisplatin delivered intravenously on days 1 and 4, $100 \mathrm{mg} / \mathrm{m}(2)$ etoposide delivered intravenously on days $1-4$ and $1800 \mathrm{mg} / \mathrm{m}(2)$ ifosfamide delivered intravenously on days $1-4$. One hour of RHT $\left(41-43{ }^{\circ} \mathrm{C}\right)$ on days 1 and 4 was applied simultaneously with chemotherapy. Wessalowski et al. showed that 16 of these patients achieved complete remission and 14 achieved partial remission. The 5-year EFS and OS was 62 and $72 \%$, respectively, and toxicity was tolerable with only reports of WHO grade 3-4 neutropenia and thrombocytopenia occurring after all chemotherapy cycles. This was the first data showing that RHT combined with PEI could improve the long-term outcome of children and adolescents with refractory or recurrent malignant non-testicular germ-cell tumours.

Notably, more recent data from adult patients with high-risk soft tissue sarcomas treated within the EORTC 62961/ESHO randomised trial showed that peri-operative chemotherapy combined with RHT significantly improved either disease-free survival or OS [13, 14], supporting combined RHT and chemotherapy as a reference therapy for adults with high-risk soft tissue sarcomas. These results indicated that RHT not only improved the local chemotherapy effect, but that it may also have stimulated immunological processes which could permit longer-term tumour control $[15,16]$. Whether this approach would also be successful in first-line treatment of paediatric patients with sarcomas has yet to be demonstrated.

\section{Further hyperthermia procedures}

There are no data from trials combining RHT and radiation therapy (thermoradiotherapy) in paediatric patients, however, the limited experience reported in case reports on paediatric patients support that application would probably have similar synergistic effects as in adults. Results from the combination of radiation therapy and hyperthermia for locally advanced cervical cancer in adult patients are worth mentioning in this context. The Dutch Deep Hyperthermia Trial not only showed an $83 \%$ local control rate for combined radiation therapy and RHT versus $57 \%$ for radiation therapy alone, but also a 3-year OS of $51 \%$ for radiation therapy combined with RHT, compared to $27 \%$ with radiation therapy alone [17]. The 12-year OS was still almost twice as high after combined radiation therapy and RHT (37\%), versus $20 \%$ with radiation therapy alone [18].

There is currently no data available for whether the post-operative use of RHT together with radiation therapy in on paediatric patients is beneficial compared to radiation therapy alone. It remains unclear whether radiation therapy could be omitted under certain circumstances and the $\mathrm{R} 1$ area treated instead with a combination of RHT and chemotherapy. Future prospective trials are necessary to evaluate the outcome and toxicities of these approaches [18].

\section{Whole-body hyperthermia}

Less is known regarding whole-body hyperthermia in children, a procedure aiming to establish a steady state with maximal temperatures of $42{ }^{\circ} \mathrm{C}$ that is maintained for $1 \mathrm{~h}$. Such a procedure can be achieved only with deep analgesia and sedation or general anaesthesia using radiant systems which have been reviewed before [19]. Therefore, the efforts needed (including intensive medical care) are much greater than for locoregional methods. Apart from a few individual cases [19-21], there is practically no experience with whole-body hyperthermia in children. There is also no solid data available on the use of whole-body hyperthermia in adults [19].

\section{Special indications such as desmoid tumours/aggressive fibromatosis}

There were a number of positive reports on RHT and its combination with radiation therapy in patients with desmoid tumours. To date, some limited data for individual cases in paediatric patients support that it could be an appropriate second-line option for complex refractory situations [22-25].

\section{Discussion}

\section{Technical solutions for RHT in children}

In paediatrics, body weights range from under $5 \mathrm{~kg}$ to adult weight. This means that the technical requirements for the widely differing weights and, thus, widely

Table 2 Available applicators for use in children and adolescents

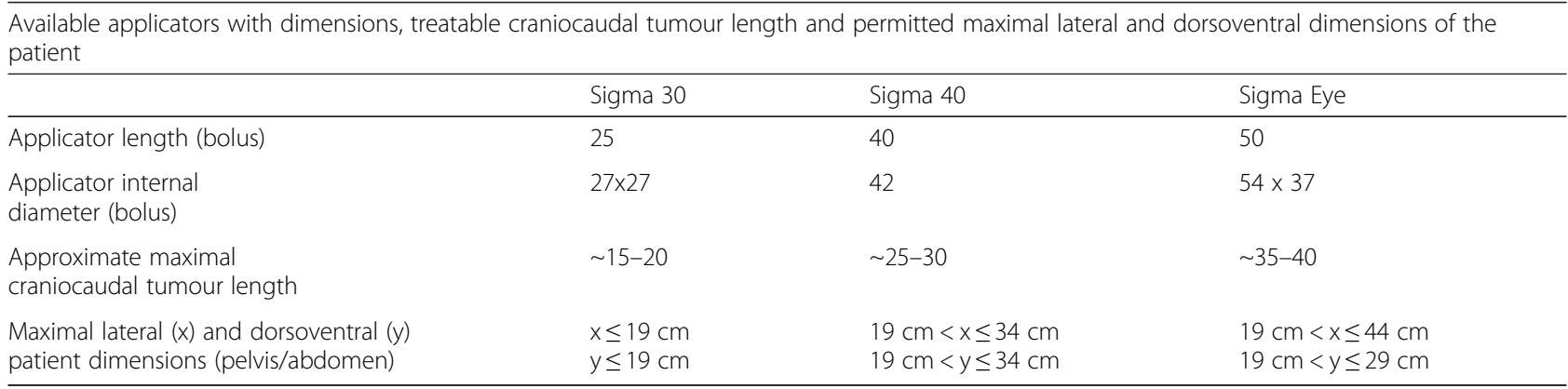


differing body and organ dimensions are complex. In addition to the special body dimensions in children, their stress tolerance for RHT is considerably lower and decreases with the age of the child. Experience has shown that from the beginning of puberty children are able to tolerate an RHT session without deep sedation or general anaesthesia. Table 2 shows the dimensions of the commercially available applicators that can be used in children together with the respective patient and tumour dimensions treatable. These technical solutions can generate intratumoral temperatures of up to $43{ }^{\circ} \mathrm{C}$, which correspond to the successful treatment protocols in children and adults.

\section{Feasibility in children and side effects}

The same body regions accessible in adults are accessible in children, with bones, lungs and the CNS being difficult to reach in all patients regardless of age. Children do have some special needs during RHT, however, and require more analgesics and need them applied earlier in combination with deep sedation or anaesthesia during RHT application [11, 12]. There are no concerns against RHT in combination with deep sedations or narcosis, although the temperature around certain organs at risk, including the skin, must be monitored carefully because of the missing perception of pain. Side effects of RHT are temperature-associated and generally rare events, as children are considerably more tolerant to temperature elevation than adults. Genuine burns are very rare. The greater risk is associated with the additional chemotherapy or radiation therapy and their associated toxicities. RHT offers a possible method to intensify local therapy without significant additional toxicity.

\section{Conclusion}

RHT can be considered for children with solid tumours, particularly germ cell tumours and soft-tissue sarcomas, and in cases of refractory tumours, recurrences or situations where standard treatments cannot be used. RHT should be applied early in the relapse situation. An important conclusion from the analysed trials is the observation that patients with recurrent germ cell tumours can be cured by RHT, even in cases where cispatin resistence arose during earlier therapy. RHT could be considered in individual cases with complex refractory situations for rare tumours, such as desmoid tumours. Currently available data from children $[8,12]$ and the more recent data from adults with soft tissue sarcomas [14] indicate that RHT could be an effective treatment option that should be further developed and investigated in children. Long-term immunological effects that potentially result from the heat-shock reaction should be closely monitored in children receiving RHT [26, 27], since clinical data to date suggest that the effects go beyond improved local control [14]. A prospective treatment optimisation trial for RHT combined with chemotherapy in the second-line treatment of sarcomas in children, adolescents and young adults is in preparation at the Charité - Universitätsmedizin Berlin.

\section{Competing interests}

The authors declare that they have no competing interests.

\section{Authors' contributions}

All authors participated in the drafting and revising of the manuscript. All authors read and approved the final manuscript.

\section{Acknowledgements}

The authors thank K. Astrahantseff for article proofreading.

\section{Author details}

${ }^{1}$ Department of Paediatric Oncology and Haematology, Otto-Heubner Centrum für Kinder- und Jugendmedizin, Charité - Universitätsmedizin Berlin, Augustenburger Platz 1, 13353 Berlin, Germany. ${ }^{2}$ Department of Radiation Oncology, Charité - Universitätsmedizin Berlin, Augustenburger Platz 1, 13353 Berlin, Germany. ${ }^{3}$ Comprehensive Cancer Center, Charité -

Universitätsmedizin Berlin, Virchowweg 23, 10115 Berlin, Germany.

Received: 21 January 2016 Accepted: 21 April 2016

Published online: 30 April 2016

\section{References}

1. Sangkhathat S. Current management of pediatric soft tissue sarcomas. World J Clin Pediatr. 2015:4:94-105.

2. Ben Arush M, Minard-Colin V, Mosseri V, Defachelles AS, Bergeron C, Algret N, et al. Does aggressive local treatment have an impact on survival in children with metastatic rhabdomyosarcoma? Eur J Cancer. 2015;51:193-201.

3. Wust P, Hildebrandt B, Sreenivasa G, Rau B, Gellermann J, Riess H, et al. Hyperthermia in combined treatment of cancer. Lancet Oncol. 2002;3:487-97.

4. Cihoric N, Tsikkinis A, van Rhoon G, Crezee H, Aebersold DM, Bodis S, et al. Hyperthermia-related clinical trials on cancer treatment within the ClinicalTrials.gov registry. Int J Hyperthermia. 2015;31:609-14.

5. Kok HP, Wust P, Stauffer PR, Bardati F, van Rhoon GC, Crezee J. Current state of the art of regional hyperthermia treatment planning: a review. Radiat Oncol. 2015;10:196.

6. Oei AL, Vriend LE, Crezee J, Franken NA, Krawczyk PM. Effects of hyperthermia on DNA repair pathways: one treatment to inhibit them all. Radiat Oncol. 2015;10:165.

7. Schneider DT, Wessalowski R, Calaminus G, Pape H, Bamberg M, Engert J, et al. Treatment of recurrent malignant sacrococcygeal germ cell tumors: analysis of 22 patients registered in the German protocols MAKEI 83/86, 89, and 96. J Clin Oncol. 2001;19:1951-60.

8. Wessalowski R, Schneider DT, Mils O, Friemann V, Kyrillopoulou O, Schaper J, et al. Regional deep hyperthermia for salvage treatment of children and adolescents with refractory or recurrent non-testicular malignant germ-cell tumours: an open-label, non-randomised, single-institution, phase 2 study. Lancet Oncol. 2013;14:843-52.

9. Wessalowski R, Schneider DT, Mils O, Hannen M, Calaminus G, Engelbrecht $V$, et al. An approach for cure: PEl-chemotherapy and regional deep hyperthermia in children and adolescents with unresectable malignant tumors. Klin Padiatr. 2003;215:303-9.

10. Romanowski R, Schott C, Issels R, Klingebiel T, Treuner J, Jurgens H, et al. Regional hyperthermia with systemic chemotherapy in children and adolescents: feasibility and clinical follow-up of 34 intensively pretreated patients with prognostically unfavorable tumor diseases. Klin Padiatr. 1993; 205:249-56

11. Wessalowski R, Blohm M, Calaminus G, Engert J, Harms D, Krause I, et al. Treatment results in children and adolescents with loco-regional recurrences of abdominal germ cell tumors (GCTs): a pilot-study with PEI chemotherapy and regional deep hyperthermia (RHT) in comparison to a matched cohort. Klin Padiatr. 1997;209:250-6.

12. Wessalowski R, Kruck H, Pape H, Kahn T, Willers R, Gobel U. Hyperthermia for the treatment of patients with malignant germ cell tumors: a phase $|/| \mid$ study in ten children and adolescents with recurrent or refractory tumors. Cancer. 1998;82:793-800. 
13. Issels RD, Lindner LH, Verweij J, Wust P, Reichardt P, Schem BC, et al. Neoadjuvant chemotherapy alone or with regional hyperthermia for localised high-risk soft-tissue sarcoma: a randomised phase 3 multicentre study. Lancet Oncol. 2010;11:561-70.

14. Issels R. Long-term follow-up of EORTC study strongly supports adding regional hyperthermia to neoadjuvant chemotherapy. Wien: ESMO; 2015.

15. Li GC, Mivechi NF, Weitzel G. Heat shock proteins, thermotolerance, and their relevance to clinical hyperthermia. Int J Hyperthermia. 1995;11:459-88.

16. Suto $R$, Srivastava PK. A mechanism for the specific immunogenicity of heat shock protein-chaperoned peptides. Science. 1995;269:1585-8.

17. van der Zee J, Gonzalez Gonzalez D, van Rhoon GC, van Dijk JD, van Putten WL, Hart AA. Comparison of radiotherapy alone with radiotherapy plus hyperthermia in locally advanced pelvic tumours: a prospective, randomised, multicentre trial. Dutch Deep Hyperthermia Group. Lancet. 2000:355:1119-25.

18. Franckena M, Stalpers $L$, Koper PC, Wiggenraad RG, Hoogenraad WJ, van Dijk JD, et al. Long-term improvement in treatment outcome after radiotherapy and hyperthermia in locoregionally advanced cervix cancer: an update of the Dutch Deep Hyperthermia Trial. Int J Radiat Oncol Biol Phys. 2008;70:1176-82.

19. Lindner H, Tillig B. Treatment of recurrent neuroblastoma in childhood with whole body thermochemotherapy. Padiatrie und Grenzgebiete. 1993:31:187-94.

20. Ismail-Zade RS, Zhavrid EA, Potapnev MP. Whole body hyperthermia in adjuvant therapy of children with renal cell carcinoma. Pediatr Blood Cancer. 2005;44:679-81.

21. Willnow $U$, Lindner $H$, Brock D, Wild L, Diestelhorst $C$, Greiner $C$, et al. Treatment of otherwise incurable tumor diseases in childhood using wholebody hyperthermia and chemotherapy. Deutsche medizinische Wochenschrift. 1989;114:208-13.

22. Ishikawa H, Hirakawa H, Takahashi K, Kawashima Y, Yoshida T, Isobe T, et al. Hyperthermia in the treatment of recurrent abdominal desmoid tumor. Gan to kagaku ryoho Cancer Chemotherapy. 2014;41:2484-6.

23. Oohata Y, Mibu R, Uehara S, lida M, Ishikawa M, Sakai M, et al. Regression of an aggressive abdominal desmoid tumor in a patient with familial adenomatous polyposis by hyperthermoradiotherapy. Am J Gastroenterol. 1997;92:156-8

24. Tkachev SI, Aliev MD, Glebovskaia W, Ivanov SM, Trofimova OP, Karapetian $\mathrm{RM}$, et al. Thermoradiotherapy as a component of desmoid tumor management: 10-year experience. Vopr Onkol. 2005;51:347-9.

25. Tkachev SI, Karapetian RM, Ivanov SM, Razuvaev VA, Sholokhov VN, Nazarenko AV, et al. Radio- and thermoradiotherapy of patients with aggressive fibromatosis. Vopr Onkol. 1999;45:663-4.

26. Jolesch A, Elmer K, Bendz H, Issels RD, Noessner E. Hsp70, a messenger from hyperthermia for the immune system. Eur J Cell Biol. 2012;91:48-52.

27. Srivastava P. Interaction of heat shock proteins with peptides and antigen presenting cells: chaperoning of the innate and adaptive immune responses. Annu Rev Immunol. 2002;20:395-425.

\section{Submit your next manuscript to BioMed Central and we will help you at every step:}

- We accept pre-submission inquiries

- Our selector tool helps you to find the most relevant journal

- We provide round the clock customer support

- Convenient online submission

- Thorough peer review

- Inclusion in PubMed and all major indexing services

- Maximum visibility for your research

Submit your manuscript at www.biomedcentral.com/submit

) Biomed Central 